\title{
Interleukin 10 (IL-10): an immunosuppressive factor and independent predictor in patients with metastatic renal cell carcinoma
}

\author{
F Wittke1, R Hoffmann, J Buer2,*, I Dallmann', K Oevermann, S Sel, T Wandert'1, A Ganser ${ }^{1}$ and J Atzpodien' \\ ${ }^{1}$ Department of Hematology and Oncology, Medizinische Hochschule Hannover, Germany; ${ }^{2}$ Department of Experimental Immunology, Institut Necker, Paris, \\ France; *Department of Cell Biology and Immunobiology, National Centre for Biotechnology (GBF) , Mascheroder Weg 1, Brannschweig, Germany
}

\begin{abstract}
Summary Interleukin 10 (IL-10) is an immunosuppressive factor and has been detected in tumour cell cultures of renal cell carcinoma and of malignant melanoma. IL-10 has been described as a cytokine of the Th2 response; it is able to suppress antigen-presenting cells (APCs) and may lead to down-regulation of HLA class I and II molecules on dendritic cells and to anergy of T-lymphocytes. We evaluated pretreatment serum levels of soluble IL-10 and various clinical parameters to determine their prognostic value in 80 advanced renal cell carcinoma patients seen at our institution between May 1990 and April 1996. For statistical evaluation we used both univariate and multivariate Cox proportional hazards models. An elevated pretreatment serum level of IL-10 was a statistically independent predictor of unfavourable outcome $(P<0.0028)$, in addition to the well-known clinical and biochemical risk factors. These data support risk stratification for future therapeutic trials and identify a predictor which needs to be validated in prospective studies and may potentially influence decision making in palliative management of patients with metastatic renal cell carcinoma. These data also suggest a potential role of IL-10 in the development of advanced renal cell carcinoma and in the future design of therapeutic strategies.
\end{abstract}

Keywords: predictors, renal cell carcinoma, IL-10

Interleukin 10 (IL-10), originally defined as cytokine synthesis inhibitory factor produced by type 2 helper T-lymphocytes (Fiorentino et al, 1989), has subsequently been described as a potentially immunosuppressive cytokine. By interfering with the co-stimulatory function of antigen-presenting cells (APCs), e.g. regulation of class II MHC expression of monocytes (deWaal Malefyt et al, 1991), and co-stimulatory molecule expression of macrophages (Ding et al, 1993), IL-10 reduces antigen-specific T-cell proliferation. Moreover, a direct effect of IL-10 on IL-2 production by activated T-cells has been observed (deWaal Malefyt et al, 1993). It has been demonstrated that IL-10 blocks the development of predendritic cells into mature dendritic cells (DCs) in vitro (Buelens et al, 1997).

This IL-10-mediated immunosuppression represents an important escape mechanism of tumours and needs further clinical investigation.

Therefore, using a highly sensitive enzyme-linked immunosorbent assay (ELISA) recognizing both human and viral IL-10, we measured the serum concentrations of IL-10 in 80 consecutive patients with a fully documented clinicopathological history of metastatic renal cell carcinoma seen in our institution since May 1990. We assessed the potential correlation between serum IL-10 levels and the outcome of these patients.

\section{METHODS}

\section{Patients and collections of samples}

This study was approved by the institutional review board of the Medizinische Hochschule Hannover; written informed consent

Received 17 February 1998

Revised 12 June 1998

Accepted 22 June 1998

Correspondence to: J Atzpodien, Department of Hematology and Oncology, Medizinische Hochschule Hannover, 30625 Hannover, Germany was obtained from all patients prior to entry into the study. At this time, we obtained samples of peripheral blood from 80 consecutive patients with metastatic renal cell carcinoma, seen at our institution at the Medizinische Hochschule Hannover, Germany since May 1990. Sera were frozen at $-80^{\circ} \mathrm{C}$ until analysis.

Patient characteristics are summarized in Table 1; all patients had a Karnovsky performance status $\geq 70 \%$, and presented with histologically confirmed metastatic renal cell carcinoma and with clinically progressive disease as demonstrated by standard radiographic procedures. Patients received systemic immunotherapy with subcutaneous IL-2 and interferon-alpha (Atzpodien et al, 1995); treatment was continued until disease progression occurred. Survival was measured from start of systemic therapy.

\section{ELISA for IL-10}

Pretreatment levels of soluble IL-10 were determined using an ELISA assay (IL-10, Medgenix, Ratingen, Germany). All analyses were performed in duplicate, strictly according to the procedures recommended by the manufacturers, and samples were analysed at a dilution resulting in measured concentrations within the range of the standard curves. Normal donor sera showed no measurable IL-10 serum levels in this assay. Sensitivity was at $0.208 \mathrm{pg} \mathrm{ml}^{-1}$ with a range of $0.78-50 \mathrm{pg} \mathrm{ml}^{-1}$. Cross-reactivity was specified with less than $1 \%$.

\section{Statistical analysis}

The statistical end point in our analysis was overall survival from time of entry into the study. We calculated univariate hazard ratios with $95 \%$ confidence intervals, using the Cox proportional hazards model. The simultaneous prognostic effect of various factors was determined in a multivariate analysis using a Cox 
Table 1 Patient characteristics

\begin{tabular}{|c|c|c|c|}
\hline Variable & $n$ & $\begin{array}{c}\mathrm{IL}-10 \leq 1 \mathrm{pg} \mathrm{ml}^{-1} \\
n^{\mathrm{a}}\end{array}$ & $\begin{array}{c}\mathrm{IL}-10>1 \mathrm{pg} \mathrm{ml}^{-1} \\
n\end{array}$ \\
\hline Patients & 80 & 59 & 21 \\
\hline \multicolumn{4}{|l|}{ Sex } \\
\hline Male & 60 & 44 & 16 \\
\hline Female & 20 & 15 & 5 \\
\hline \multicolumn{4}{|c|}{ Age (years) } \\
\hline Mean & 57 & 56 & 57 \\
\hline Range & $32-74$ & $37-72$ & $32-74$ \\
\hline \multicolumn{4}{|c|}{ Metastases } \\
\hline Lung & 59 & 43 & 16 \\
\hline Bone & 23 & 17 & 6 \\
\hline Liver & 20 & 13 & 7 \\
\hline Brain & 11 & 8 & 3 \\
\hline \multicolumn{4}{|c|}{ Tumour sites } \\
\hline 1 & 28 & 24 & 4 \\
\hline$>1$ & 52 & 35 & 17 \\
\hline
\end{tabular}

aSerum IL-10 levels were assayed prior to systemic therapy.

proportional hazards model (forward and reverse selection of variables). The probability of overall survival was plotted over time according to the method of Kaplan and Meier (Kaplan et al, 1958). Differences in overall survival between groups were tested as dichotomized prognostic variables. For IL-10, erythrocyte sedimentation rate (ESR) and haemoglobin, Kaplan-Meier estimates were performed defining the best cut-off value for discrimination between poor and good overall survival. For lactate dehydrogenase (LDH), the institutional upper normal limits were chosen as the cut-off $\left(240 \mathrm{U} \mathrm{l}^{-1}\right)$.

\section{RESULTS}

\section{Univariate analysis of pretreatment variables and survival}

We analysed the ability of various clinical factors and of serum levels of soluble IL-10 to predict clinical outcome. The mean period of follow-up for the surviving patients was $32+$ months (range, $2-80+$ months). The median survival of all 80 patients entering the study was $21+$ months.

We calculated univariate $P$-values with the Kaplan-Meier model (Table 2). In this analysis, IL-10, LDH, haemoglobin and ESR had significant prognostic impact on overall survival. Elevated serum levels of IL-10 (> $\left.1 \mathrm{pg} \mathrm{ml}^{-1}\right)$ were detected in 21 patients and were strongly associated with an unfavourable outcome. Median survival in these patients was $11+$ months as opposed to patients with low IL-10 levels $\left(\leq 1 \mathrm{pg} \mathrm{ml}^{-1}, n=59\right)$ who had a median survival of $27+$ months $(P<0.0028)$.

All other variables investigated (sex, age, time between diagnosis and progression, lung metastases, bone metastases, liver metastases, brain metastases and local relapse) were not statistically significant for the prediction of patient survival.

\section{Multivariate analysis of risk factors}

To identify the most powerful independent predictors, we established a multivariate Cox proportional hazards model containing those factors with significant prognostic value upon univariate analysis. All four univariate risk factors were found to be
Table 2 Impact of pretreatment serum IL-10 levels and clinical factors on patient survival in 80 consecutive patients with advanced renal cell carcinoma by univariate analysis

\begin{tabular}{|c|c|c|}
\hline Variable & Categories compareda & $P$-value \\
\hline \multicolumn{3}{|l|}{ Clinical factors } \\
\hline Sex & Female vs. male & 0.89 \\
\hline Age (years) & $<60$ vs. $\geq 60$ & 0.155 \\
\hline $\begin{array}{l}\text { Time between diagnosis } \\
\text { and progression } \\
\text { (months) }\end{array}$ & $>12$ vs. $\leq 12$ & 0.16 \\
\hline Haemoglobin $\left(\mathrm{g} \mathrm{dl}^{-1}\right)$ & $\geq 10$ vs. $<10$ & 0.0000 \\
\hline $\operatorname{ESR}\left(\mathrm{mm} \mathrm{h}^{-1}\right)$ & $<50$ vs. $\geq 50$ & 0.0004 \\
\hline $\mathrm{LDH}\left(\mathrm{U}^{-1}\right)$ & $<240$ vs. $\geq 240$ & 0.016 \\
\hline Lung metastases & Present vs. absent & 0.86 \\
\hline Bone metastases & Absent vs. present & 0.18 \\
\hline Liver metastases & Absent vs. present & 0.92 \\
\hline Brain metastases & Absent vs. present & 0.12 \\
\hline Local relapse & Absent vs. present & 0.35 \\
\hline $\mathrm{IL}-10\left(\mathrm{pg} \mathrm{ml}^{-1}\right)$ & $\leq 1$ vs. $>1$ & 0.0028 \\
\hline
\end{tabular}

aFor each variable, the prognostic significance of the first category listed was assessed by comparing that category with the reference category (the second category listed).

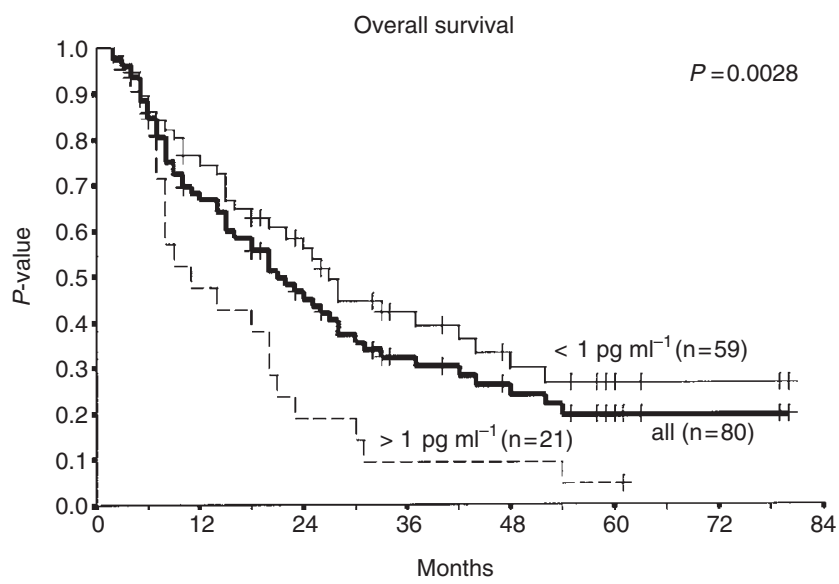

Figure 1 Serum IL-10 and survival in 80 patients with metastatic renal cell carcinoma. Survival curves (Kaplan-Meier estimate) of patients with either low $\left(\leq 1 \mathrm{pg} \mathrm{ml}^{-1}\right)$ or elevated $\left(>1 \mathrm{pg} \mathrm{ml}^{-1}\right)$ serum levels of IL-10. $P$-value was determined by log rank test. Tick marks represent patients for whom data were censored.

statistically independent: haemoglobin $<10 \mathrm{~g} \mathrm{dl}^{-1}(P=0.0005)$, ESR $\geq 50 \mathrm{~mm} \mathrm{~h}^{-1}(P=0.049)$, serum $\mathrm{LDH} \geq 240 \mathrm{U}^{-1}(P=$ $0.0233)$ and serum IL-10 $>1 \mathrm{pg} \mathrm{ml}^{-1}(P=0.0226)$. The hazard ratios calculated with a model containing these prognostic factors are shown in Table 3.

\section{DISCUSSION}

Our study demonstrated that elevated pretreatment serum IL-10 is a potentially powerful and independent predictor of overall survival in patients with metastatic renal cell carcinoma. Both by univariate and multivariate analysis, serum IL-10 $(P=0.0226)$, serum LDH $(P=0.0233)$, haemoglobin $(P=0.0005)$ and ESR $(P=0.049)$ were predominant independent predictors of survival; by demonstrating statistic independence, IL-10 adds new information to previously identified risk factors. 
Table 3 Hazard ratios associated with pretreatment predictors of overall survival in a multivariate analysis of 80 consecutive patients with metastatic renal cell carcinoma, using Cox proportional hazards models

\begin{tabular}{lccc}
\hline Variable & Categories compared & \\
\hline Clinical factors & $\begin{array}{c}\text { Hazard ratio } \\
(\mathbf{9 5 \%} \text { confidence interval) }\end{array}$ & $\boldsymbol{P}^{\text {-value }}{ }^{\text {b }}$ \\
LDH $\left(\mathrm{U} \mathrm{l}^{-1}\right)$ & $<240$ vs. $\geq 240$ & & \\
ESR $\left(\mathrm{mm} \mathrm{h}^{-1}\right)$ & $<50$ vs. $\geq 50$ & $0.48(0.26-0.89)$ & 0.0233 \\
Haemoglobin $\left(\mathrm{g} \mathrm{dl}^{-1}\right)$ & $\geq 10$ vs. $<10$ & $0.31(0.15-0.65)$ & 0.049 \\
Interleukin 10 $\left(\mathrm{pg} \mathrm{ml}^{-1}\right)$ & $\leq 1$ vs. $>1$ & $0.20(0.09-0.45)$ & 0.0005 \\
& & $0.50(0.26-0.89)$ & 0.0226 \\
\hline
\end{tabular}

aFor each variable, the prognostic significance of the first category listed was assessed by comparing that category with the reference category (the second category listed). ${ }^{b}$ For the comparison of the hazard ratio shown with a hazard ratio of 1.0 (as postulated by the null hypothesis).

We have shown previously that elevated serum LDH, elevated ESR and decreased haemoglobin may correlate with tumour load and with poor outcome in patients with metastatic renal cell carcinoma (Lopez-Hänninen et al, 1995).

IL-10 has been detected in different human tumours, e.g. malignant melanoma and renal cell carcinoma (Wang et al, 1995). The location of the compartment of IL-10 secretion remains to be identified in humans with malignant disease. Tumour-infiltrating lymphocytes and tumour cells of renal cell carcinoma themselves have been detected as source for IL-10 (Dummer et al, 1996; Knoefel et al, 1997). The reason for the elevated IL-10 production still remains unclear. The elevated serum IL-10 levels that we found may be correlated with a high intratumoral IL-10 production. As Buer et al (1998) recently demonstrated, IL-10 can be produced by anergic T-lymphocytes and is able to contribute to T-cell anergy. Intratumorally produced IL-10 may therefore lead to anergy of tumour-infiltrating lymphocytes and thereby support intratumoral tolerance. This may be a reason for rapid progression of some patients with malignant disease.

Other malignant diseases have been demonstrated to show a similar mechanism. Thus, elevated serum IL-10 levels have been demonstrated as a negative prognostic factor in patients with active non-Hodgkin's lymphoma (Blay et al, 1993).

In conclusion, in the present study, elevated pretreatment serum levels of IL-10 correlate with poor outcome in renal cell carcinoma. These data may contribute to a better patient selection via risk stratification for future therapeutic trials. This factor may potentially influence the decision-making of available immunotherapeutic strategies of patients with metastatic renal cell carcinoma. In addition, an improved understanding of the pretreatment immunological status of patients with metastatic renal cell carcinoma may provide a lead for future therapeutic strategies focusing on the modulation of this cytokine and/or its receptor structure. Our results will have to be prospectively confirmed in future controlled studies.

\section{REFERENCES}

Atzpodien J, Lopez-Hänninen E, Kirchner H, Bodenstein H, Pfreundschuh M, Rebmann U, Metzner B, Illiger HJ, Niesel T and Poliwoda H (1995) Multiinstitutional home-therapy trial of recombinant human Interleukin-2 and Interferon- $\alpha 2$ in progressive metastatic renal cell carcinoma. J Clin Oncol 13(2): 497-501

Blay J-Y, Burdin N, Rousset F, Lenoir G, Biron P, Philip T, Banchereau J and Favrot MC (1993) Serum Interleukin-10 in non Hodgkin's lymphoma: a prognostic factor. Blood 82: 2169-2174
Buelens C, Verhasselt V, De Groote D, Thielemans K, Goldman M and Willems F (1997) Interleukin-10 prevents the generation of dendritic cells from human peripheral blood mononuclear cells cultured with interleukin-4 and granulocyte-macrophage-colony-stimulating factor. Eur J Immunol 27: 756-762

Buer J, Lanoue A, Franzke A, Garcia C, v. Boehmer H and Sarukhan A (1998) Interleukin-10 secretion and impaired effector function of MCH class iirestricted T cells anergized in vivo. J Exp Med 187: 177-183

deWaal Malefyt R, Haanen J and Spits H (1991) Interleukin 10 and viral IL-10 strongly reduce antigen-specific human $\mathrm{T}$ cell proliferation by diminishing the antigen-presenting capacity of monocytes via downregulation of class II major histocompatibility complex expression. J Exp Med 174: 915-924

deWaal Malefyt R, Yssel H and deVries JE (1993) Direct effect of IL-10 on subsets of human CD4+ T cell clones and resting T cells. J Immunol 150: 4754-4765

Ding L, Linsley P and Huang LY (1993) IL-10 inhibits macrophage costimulatory activity by selectively inhibiting the up-regulation of B7-expression. $J$ Immunol 151: $1224-1234$

Dummer W, Bastian BC, Ernst N, Schanzle C, Schwaaf A and Brocker EB (1996) Interleukin-10 production in malignant melanoma: preferential detection of Interleukin-10-secreting tumor cells in metastatic lesions. Int J Cancer 66(5): $607-610$

Fiorentino DF, Bond MW and Mosmann TR (1989) Two types of mouse T helper cells. IV. Th 2 clones secrete a factor that inhibits cytokine production by Th1 clones. J Exp Med 170: 2081-2095

Kaplan EL and Meier P (1958) Non-parametric estimation from incomplete observations. J Am Stat Assoc 53: 457-481

Knoefel B, Nuske K, Steiner T, Junker K, Kosmehl H, Rebstock K, Reinhold D and Junker U (1997) Renal cell carcinomas produce IL-6, IL-10, IL-11 and TGFbeta1 in primary cultures and modulate T-lymphocyte blast transformation. J Interferon Cytokine Res 17: 95-102

Kruger-Krasagakes S, Krasagakis K, Garbe C, Schmitt E, Huls C, Blankenstein T and Diamantstein T (1994) Expression of Interleukin-10 in human melanoma. Br J Cancer 70: 1182-1185

Lopez-Hänninen E, Kirchner H and Atzpodien J (1995) Interleukin-2 based home therapy of metastatic renal cell carcinoma: risks and benefits in 215 consecutive single institution patients. J Urol 155(1): 19-25

Matsuda M, Salazar F, Petersson M, Masucci G, Hansson J, Pisa P, Zhang QJ, Masucci MG and Kiessling R (1994) Interleukin-10 pretreatment protects target cells from tumor- and allo-specific cytotoxic T cells and downregulates HLA class I expression. J Exp Med 180: 2371-2376

Nakagomi H, Pisa P, Pisa EK, Yamamoto Y, Halapi E, Backlin K, Juhlin C and Kiessling R (1995) Lack of interleukin-2 (IL-2) expression and selective expression of IL-10 mRNA in human renal cell carcinoma. Int J Cancer 63: 366-371

Suzuki T, Tahara H, Narula S, Moore KW, Robbins PD and Lotze MT (1995) Viral Interleukin-10 (IL-10), the human herpes virus 4 cellular IL-10 homologue, induces local anergy to allogeneic and syngeneic tumors. J Exp Med 182: 477-486

Wang Q, Redovan C, Tubbs R, Olencki T, Klein E, Kudoh S, Finke J and Bukowski RM (1995) Selective cytokine gene expression in renal cell carcinoma tumor cells and tumor-infiltrating lymphocytes. Int J Cancer 61: 780-785

Yue FY, Dummer R, Geertsen R, Hofbauer G, Laine E, Manolio S and Burg G (1997) Interleukin-10 is a growth factor for human melanoma cells and downregulates HLA class-I, HLA class-II and ICAM molecules. Int J Cancer 71: $630-637$ 